\author{
上田隆雄*, 宮川豊章** \\ * 徳島大学大学院 ソシオテクノサイエンス研究部 エコシステムデザイン部門 \\ ** 京都大学 大学院 工学研究科 社会基盤工学専攻
}

\title{
Deterioration of Concrete Structures and Some Relevant Issues
}

\author{
Takao Ueda* and Toyoaki Miyagawa** \\ * Department of Civil and Environmental Engineering, Graduate School of Engineering \\ The University of Tokushima \\ ** Department of Civil and Earth Resources Engineering, Graduate School of Engineering \\ Kyoto University
}

\begin{abstract}
Performances of concrete structures should be decreased with time due to some mechanisms of deterioration such as chloride attack, carbonation of concrete and alkali aggregate reaction. Considering the establishment of an appropriate maintenance system for such structures, there are many problems to be solved. In this paper, deterioration cases of concrete structures are outlined, followed by the explanation of some investigations to build the maintenance system and remained issues, regarding mainly the problem of steel corrosion in concrete.
\end{abstract}

Keywords : concrete structure, deterioration mechanism, steel corrosion, maintenance system, repair method, scenario design

\section{1.はじめに}

かつての，コンクリート構造物はメンテナンス・フリ 一で半永久的な寿命を持つという，いわゆる「コンクリ ート神話」は過去のものとなり, 今やコンクリート構造 物の劣化問題は, 深刻な社会問題の一つと言っても過言 ではない。では，「コンクリート神話」は全くのでたら めだったのか？というと真実の部分もあり，実際に 50 年以上にわたり，ほぼメンナンス・フリーで供用され 続けてきた第一大戸川橋梁（図 1) のような例もある.こ の橋梁は, 我が国初の本格的ポストテンション PC 桁を 採用した鉄道橋であり，1954 年に旧日本国有鉄道により 架設されたものであるが，現在においても全く中性化し ていない極めて健全なコンクリートの状態を保持してい たことが報告されている11.

このように，適切に設計・施工・維持管理がなされた コンクリート構造物は，良好な性能を長期間にわたって 発揮できるものであるが，一方で，コンクリート構造物 の特性を十分に認識できなかったために，非常に短期間 で劣化が顕在化するケースも依然として多いのが現状で ある。コンクリート構造物は，これまでも，そして，今 後も社会基盤の中核をなす重要な役割を担っている。こ のため，新設の構造物については，早期に劣化すること のない，十分な耐久性を有するものでなくてはならない し, 既設の構造物については, 適切な維持管理システム の中で，所定の期間を通じた性能の保持を保証していか なくてはならない，その際に重要となるのは構造物の 「戦略的なマネジメント」であり，「場当たり的なマネジ

* =770-8506 徳島市南常三島 2-1 (2-1, Minamijosajima, Tokushima, 770-8506 Japan)

** $=$ 615-8540 京都市西京区京都大学桂 (Kyoto-daigaku Katsura, Nishikyo-ku, Kyoto, 615-8540 Japan)

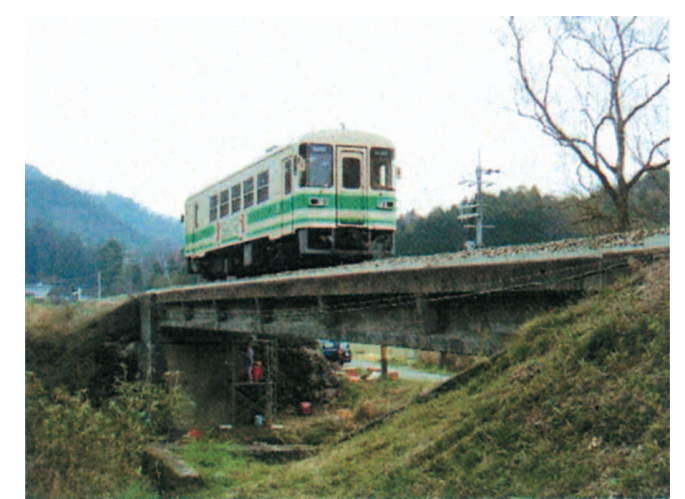

図 1 信楽高原鐵道第一大戸川橋梁

メント」では, 予定された供用期間を全うすることは困 難である.すなわち, 将来にわたる構造物の劣化進行を 予測し, 補修・補強などの対策効果も含めてその構造物 に最適な一生を設計する，いわゆるシナリオデザインの 考え方 ${ }^{2)}$ の導入が求められる.

本稿では, コンクリート構造物の劣化状況を概観する とともに，その対策としての，耐久性照査型設計，防 食・補修工法などの現状と問題点, および，これらを含 めたシナリオデザインの考え方を概説する.

\section{2. コンクリート構造物の劣化機構}

コンクリートは，それ自身が複合材料であるとともに， 鋼材との組み合わせで構造物を形成する場合がほとんど であることから, 劣化形態は複雑かつ多様である.コン クリート構造物の劣化現象の分類例を図 2 に示す。図 2 に示されるように，コンクリート構造物の劣化は一般に コンクリート自身の劣化と，コンクリート中の鉄筋腐食 に分類される ${ }^{3)}$.

コンクリート自身の劣化機構として代表的なものに 


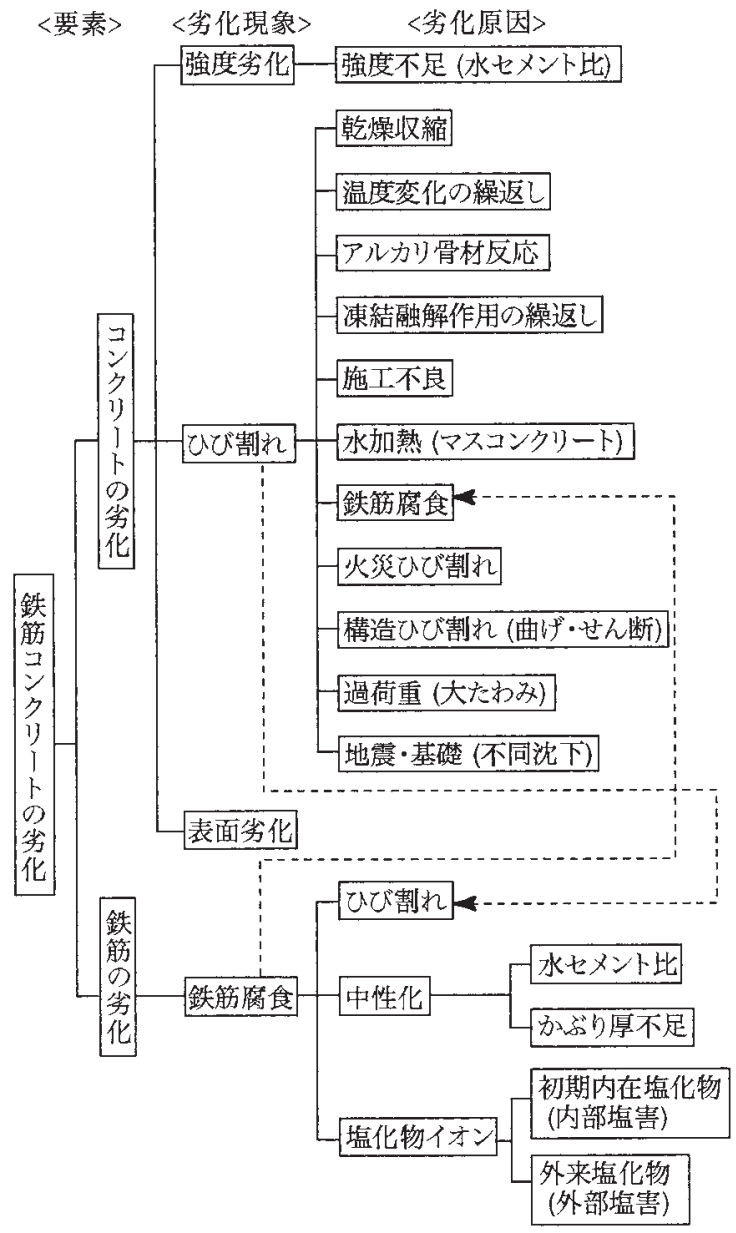

図 2 コンクリート構造物の劣化現象の分類例 33

は，凍害 (凍結融解)，アルカリ骨材反応，化学的侵食， 疲労などがある。凍害は, 冬場に寒暖の差が激しくなる 地域で発生しやすく, 北海道, 東北地方や, 山間部で多 く見られる劣化現象である. 劣化メカニズムとしては, コンクリート中の水分が凍結する際の体積膨張により, 空隙中に大きな静水圧が発生し，これがコンクリートの 引張強度に達したときにひび割れが発生するものと考え られている. 劣化形態の代表的なものとしては, 構造物 の表層部分が剥がれ落ちるスケーリング (図 3) や, 骨材 が表層から円錐状に剥離するポップアウトなどが挙げら れる. 凍害は, 凍結防止剂の散布によって劣化が加速す ることが知られている。アルカリ骨材反応は，コンクリ ートの細孔溶液中のアルカリ金属イオン $\left(\mathrm{Na}^{+}, \mathrm{K}^{+}\right)$が骨 材中の反応性鉱物と反応することで，アルカリシリカゲ ルを生成し，このゲルの吸水澎張によってコンクリート にひび割れが生じる現象である. 劣化状況は図 4 に示す ように，コンクリート表面に亀甲状のひび割れが発生し， そこから白色のゲルが浸出するケースが多い.また，近 年では, 図 4 に示したような, コンクリート中の鉄筋破 断現象も報告5) されている. 鉄筋破断については, 節形 状, 曲げ加工時発生微小亀裂, 曲げ加工部強度 $(800$ $\mathrm{N} / \mathrm{m}^{2}$ 以上 $\left.{ }^{6)}\right)$, 曲げ加工による破壊勒性低下など以外に も，現実のコンクリート構造物中の拡散性水素量 (0.1 $\mathrm{ppm}$ 程度7) ${ }^{2}$, ASR によるような低ひずみ速度における速 度依存性8) など検討すべき事項はまだ多く残されている。

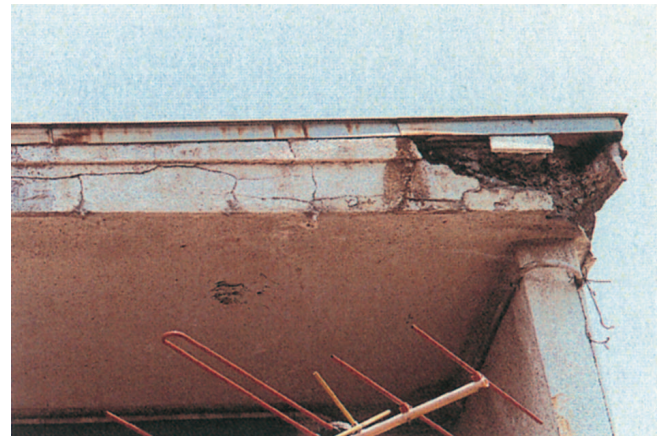

図 3 凍害によるスケーリング

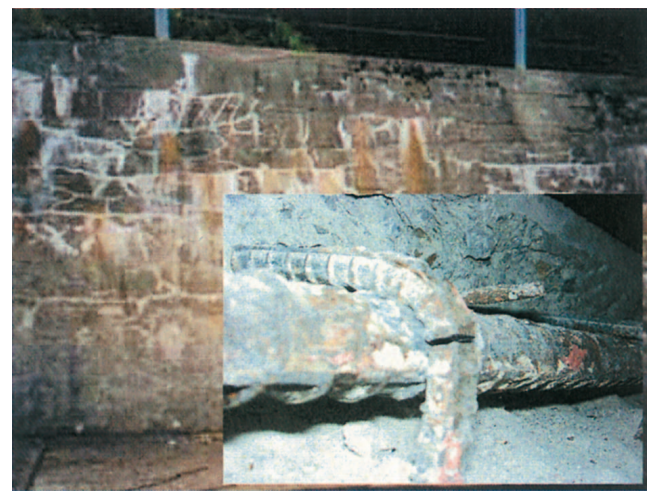

図４アルカリ骨材反応によるひび割れ状況とコンクリート中 の鉄筋破断

しかも，現実にコンクリート中で破断した鉄筋そのもの に関して，まだまだ種々の情報が不足している.

コンクリート中の鉄筋腐食を引き起こす劣化機構とし ては，中性化と塩害が挙げられる．コンクリート中の鉄 筋は一般にコンクリート内部のアルカリ性に起因して生 成する不動態被膜によって腐食から守られているが，中 性化あるいは塩害によって不動態被膜が破壊されると， 腐食反応が進行する。中性化はかぶりの薄いコンクリー 卜構造物でよく見られる現象であり, 図 5 に示されるよ うに，鉄筋上部の薄いかぶりコンクリートの浮きや剥離 が発生する. 中性化反応は下式で示され，大気中の $\mathrm{CO}_{2}$ を吸収することで，コンクリート中のアルカリ性保持の 役割を担う $\mathrm{Ca}(\mathrm{OH})_{2}$ が $\mathrm{CaCO}_{3}$ に変化してコンクリート の $\mathrm{pH}$ が低下する。

$$
\mathrm{Ca}(\mathrm{OH})_{2}+\mathrm{CO}_{2} \rightarrow \mathrm{CaCO}_{3}+\mathrm{H}_{2} \mathrm{O}
$$

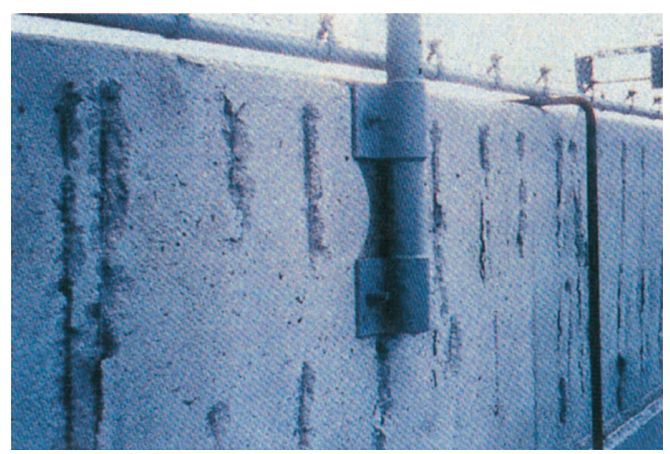

図 5 中性化による鉄筋腐食 


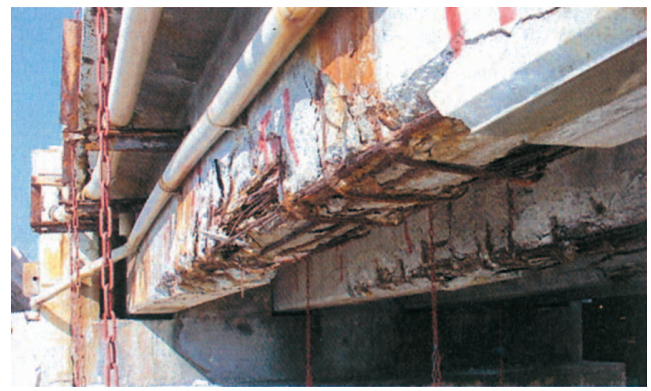

図 6 塩害による鉄筋腐食

$\mathrm{pH}$ の低下によって不動態被膜が破壊されると鉄筋腐 食が開始し，腐食生成物の膨張圧でコンクリート内部か らひび割れが発生する，塩害の場合には，海砂などから 供給される内在塩分, 海洋環境などでコンクリート外か ら供給される外来塩分の, いずれかの供給方法によって
コンクリート中に塩分が供給され, 鉄筋位置の塩分濃度 が限界值に達すると不動態被膜が破壊されて腐食が開始 する（図 6). 腐食開始後の劣化進行は基本的に中性化と 同じであるが，一般に中性化はミクロセル腐食が卓越す る全面腐食, 塩害はマクロセル腐食が卓越する局部腐食 となりやすく, 腐食速度は塩害の方が大きい傾向があ る.

\section{3. 耐久性照査の現状}

前章で示したような種々の劣化機構に対して, 十分な 耐久性を有するコンクリート構造物を設計するため，土 木学会では，コンクリート標準示方書の中で，耐久性照 査の考え方を導入している，塩害に関する耐久性照査フ ローを図 7 に示す. 図 7 において, 左端の上下方向の矢 印で示したように，横線で区切られた上部が現行のコン クリート標準示方書の考え方である腐食開始を限界状態

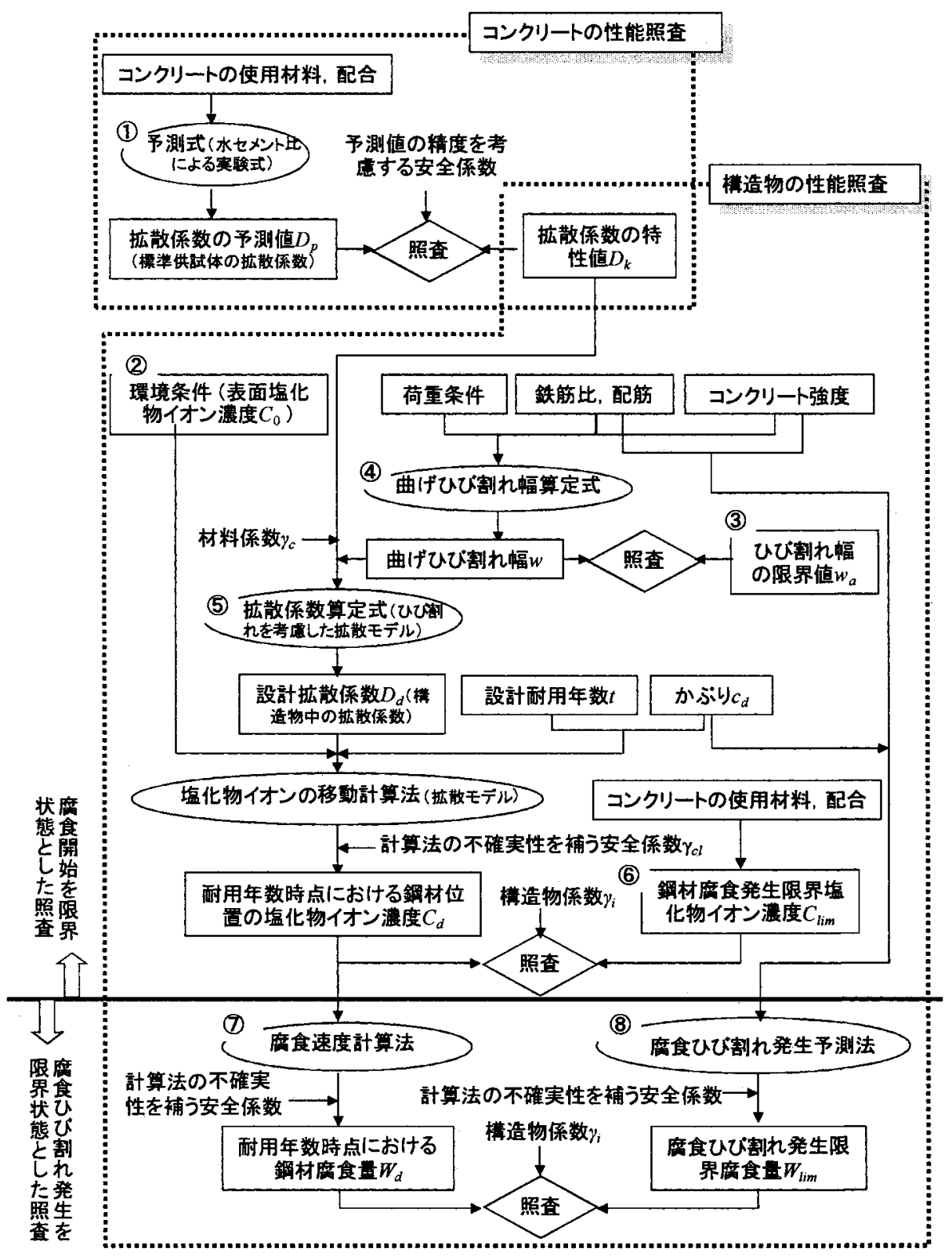

図 7 塩害に関する照査フロー9) 


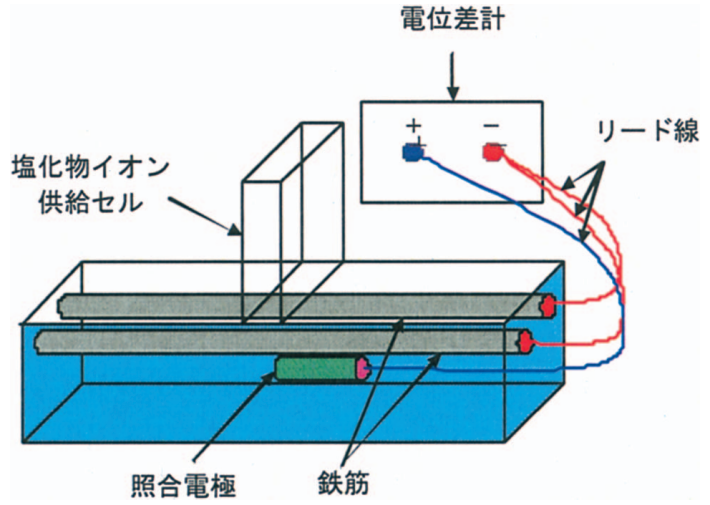

図 8 鋼材腐食発生限界 $\mathrm{Cl}^{-}$濃度測定用の試験装置 ${ }^{10)}$

とした照査であり，下部が今後の導入が期待されている 腐食ひび割れ発生を限界状態とした照査である。すなわ ち現行の示方書では, コンクリートの配合条件や, 構造 物の曲げひび割れ幅などを考慮して, $\mathrm{Cl}^{-}$の設計拡散係 数 $D_{\mathrm{d}}$ を設定する．さらに，環境条件を考慮して表面 $\mathrm{Cl}^{-}$ 濃度 $C_{0}$ を設定して，これらの值を拡散モデルに適用す ることで，将来における鋼材位置の $\mathrm{Cl}^{-}$濃度を算出し， 鋼材腐食発生 $\mathrm{Cl}^{-}$濃度 $C_{\lim }$ と比較することで, 腐食開始 の有無を照査する。ただし, この場合, 構造物の性能と しては相当に安全側の評価となるため，今後は，腐食発 生後の鋼材腐食速度を用いて将来における鋼材腐食量を 算出し, 腐食ひび割れ発生限界腐食量 $W_{\lim }$ と比較するこ とで，腐食ひび割れ発生を限界状態とした照査体系の構 築が進むものと考えられる．現状では，設計時に鋼材腐 食速度を予測することが困難であるとともに，腐食ひび 割れ発生限界腐食量 $W_{\lim }$ の值にも, 報告によって大きな ばらつきが見られるなど，課題は多い。

現行の示方書では, 鋼材腐食発生 $\mathrm{Cl}^{-}$濃度 $C_{\lim }$ として, $1.2 \mathrm{~kg} / \mathrm{m}^{3}$ を設定しているが，コンクリートの配合条件 などにより異なるものと考えられ，実験室レベルで $C_{\lim }$ の真值を得るために種々の検討がなされている．例えば, 図 8 に示すように, 鉄筋と照合電極を埋め込んだコンク リートの供試体に塩水を外部から供給し，この間の鉄筋 の自然電位のデー夕を連続的に測定する。さらに，供給 された $\mathrm{Cl}^{-}$によって鉄筋の自然電位が急変した瞬間を捉 えてコンクリート中の $\mathrm{Cl}^{-}$濃度分布を测定し, 鉄筋表面 位置の $\mathrm{Cl}^{-}$濃度を鋼材腐食発生 $\mathrm{Cl}^{-}$濃度 $C_{\lim }$ として算出 するという手法である。これは一つの検討例であるが， 測定方法によって $C_{\lim }$ の值が大きく異なることなどが問 題点として挙げられている.

土木学会コンクリート標準示方書では, ここで紹介し た塩害以外にも，中性化，凍害，アルカリ骨材反応，化 学的侵食, 疲労, すり減りなどの劣化機構についても耐 久性照査を行うことを規定しているが，凍害やアルカリ 骨材反応などのコンクリート劣化については, 設計段階 での定量的な性能照査には課題が多いのが現状である.

\section{4. 劣化診断と補修・補強対策}

劣化の有無にかかわらず既設の構造物について点検を 実施する場合には, 種々の手法を用いて調查・診断を行 い, 構造物の現状を把握するとともに, 将来における劣
化進行を予測する。さらに，予定供用期間中に構造物の 性能が要求性能を満足しないと判定された場合には，補 修・補強などの対策が必要になる。

鉄筋腐食によって劣化した構造物の場合について，主 な調査方法を表 1 に示す. 劣化の状態を直接的に把握す るには,コンクリートをはつりとって内部の鉄筋を露出 させることが最も確実な方法と言えるが, 構造物にダメ ージを与えることや，多大な労力が必要で効率的でない ことなど問題点が多い.そこで期待されているのが，非 破壊検査手法あるいは微破壊検査手法と言われるもので ある．特に鉄筋腐食の測定手法としては，自然電位，分 極抵抗やコンクリート抵抗率を測定する, 電気化学的手 法が主流となっている。自然電位法は，コンクリート表 面などに設置した照合電極とコンクリート中の鉄筋との 電位差を測定し，その值によって鉄筋の腐食状態を推定 する手法であり，比較的安価な装置を用いて簡易に構造 物中の腐食分布を推定できるため, よく用いられる手法 である，ただし，自然電位の值のみでは，構造物の劣化 予測などの定量的評価は難しい。これに対して分極抵抗 法は, 眓 9 に示したような装置を用いて, コンクリート 中の鉄筋に微弱な電流を流し, 腐食電流の流れにくさを 表す分極抵抗を測定するものである. 自然電位法よりも 高価な装置が必要となり, 測定にはやや高度な技術も必 要であるが，分極抵抗が得られれば，下記の式によって 腐食速度が算出できる点が大きな利点である。

$$
I_{\text {corr }}=k\left(1 / R_{\mathrm{p}}\right)
$$

ここに, $I_{\mathrm{corr}}$ : 腐食電流密度 $\left(\mathrm{A} / \mathrm{cm}^{2}\right), R_{\mathrm{p}}$ : 分極抵抗

\section{表 1 鉄筋腐食に対する主な調查方法9}

\begin{tabular}{|c|c|c|}
\hline $\begin{array}{l}\text { 調查の } \\
\text { 区 分 }\end{array}$ & 調査の方法 & 評価項目 \\
\hline $\begin{array}{l}\text { 目視点検 } \\
\text { たたき調 } \\
\text { 查含む) }\end{array}$ & $\begin{array}{l}\text { ひび割れ，剥離，剥落, } \\
\text { 錆汁, 遊離石灰, 変色, } \\
\text { 漏水, 変位・変形, 鉄筋 } \\
\text { 腐食状況（鉄筋露出時） }\end{array}$ & $\begin{array}{l}\text { 構造物の外観上のグレ } \\
\text {-ド } \\
\text { 鉄筋の腐食のグレード }\end{array}$ \\
\hline \multirow{2}{*}{$\begin{array}{ll}\text { 破 } & \text { 壤 } \\
\text { 検 査 }\end{array}$} & \multirow{2}{*}{ はつり調查 } & 鉄筋径 \\
\hline & & 腐食減量 \\
\hline \multirow{5}{*}{$\begin{array}{l}\text { 微破壞 } \\
\text { 非破壞 } \\
\text { 検 查 }\end{array}$} & 自然電位法 & 自然電位 \\
\hline & 交流インピーダンス法 & 分極抵抗 \\
\hline & 直線分極抵抗法 & 分極抵抗 \\
\hline & 四電極法 & コンクリート抵抗率 \\
\hline & 位相角法 & 電気 2 重層容量 \\
\hline \multirow{3}{*}{$\begin{array}{l}\text { 非破壊 } \\
\text { 検査(研 } \\
\text { 究段階) }\end{array}$} & 電磁パルス法 & \\
\hline & $\mathrm{AE}$ 法 & \\
\hline & 電磁誘導加熱法 & \\
\hline \multirow{6}{*}{$\begin{array}{l}\text { 埋 設 } \\
\text { センサ }\end{array}$} & 自然電位 & 腐食の可能性 \\
\hline & マクロセル腐食電流 & \multirow{3}{*}{$\begin{array}{l}\text { 深さ方向の腐食環境の } \\
\text { 変化を評価 }\end{array}$} \\
\hline & 電気抵抗 & \\
\hline & 電位差 & \\
\hline & 分極抵抗 & 腐食の有無，速度 \\
\hline & pH センサ & 腐食環境 \\
\hline $\begin{array}{l}\text { 非破壊 } \\
\text { 非接触 }\end{array}$ & 近赤外分光法 & $\begin{array}{l}\text { コンクリートの表層部 } \\
\text { の塩化物量 }\end{array}$ \\
\hline 非破壊 & 電磁波法 & $\begin{array}{l}\text { かぶりコンクリートの } \\
\text { 塩化物量 } \\
\end{array}$ \\
\hline
\end{tabular}




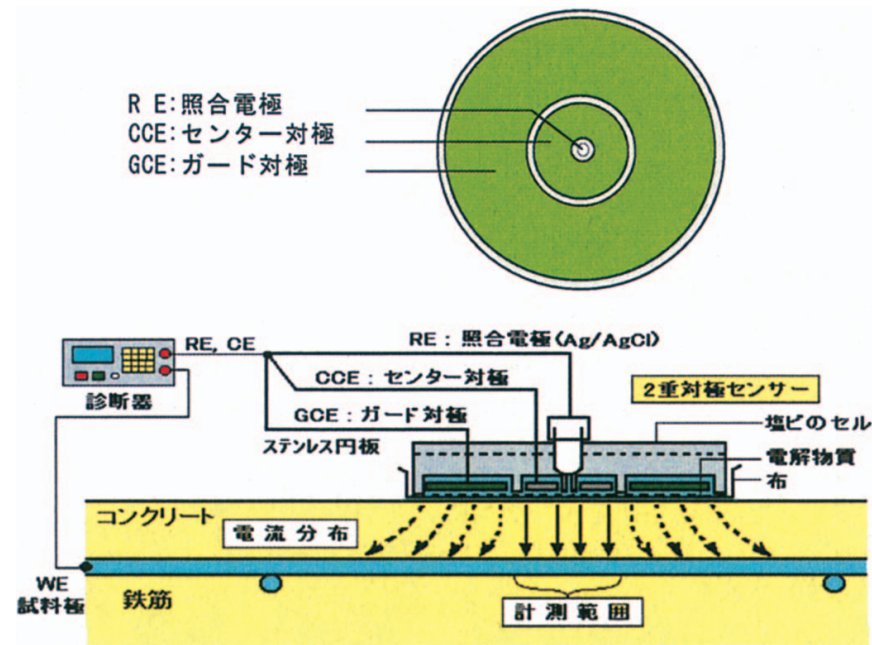

図 9 分極抵抗測定方法の例9)

$\left(\Omega \cdot \mathrm{cm}^{2}\right), k$ : 比例定数を示す.

上式に示した $I_{\text {corr }}$ が腐食速度に相当し，この值が算出 できれば，鉄筋腐食進行による劣化予測が可能となる。 ただし, 現状では (2) 式中の比例定数 $k$ の值に諸説があ り, 精度の高い腐食量推定にはまだ課題が残されている と言える。

劣化したコンクリート構造物の補修工法には多くの種 類があるが，代表的なものを挙げると図 10 に示す通り である.比較的古くから用いられ適用実績の多いのは, 表面被覆工法や断面修復工法であるが，劣化状況によっ ては効果が小さく再劣化の可能性もあることから, 近年 注目されているのが電気化学的手法である ${ }^{11)}$. 代表的な 電気化学的手法である脱塩工法と再アルカリ化工法につ いて，その原理を図 11 に示す。これらの手法では, 共 通してコンクリート構造物の表面部分に陽極材を設置 し，コンクリート中の鉄筋を陰極として直流電流を供給 する。これにより，脱塩工法の場合には，塩害の原因と なるコンクリート中の $\mathrm{Cl}^{-}$が陽極材のあるコンクリート 表面方向に電気泳動によって移動し, コンクリート外に 抽出できる。再アルカリ化工法は，コンクリート表面の 陽極材近傍に保持したアルカリ性の電解液が中性化した コンクリート中に電気浸透によって移動し，コンクリー トの $\mathrm{pH}$ を上昇させることができる。いずれの手法も本 格的に適用され始めて 10 年程度の新しい工法であるが, 効果が確認されることで施工実績を伸ばしている.

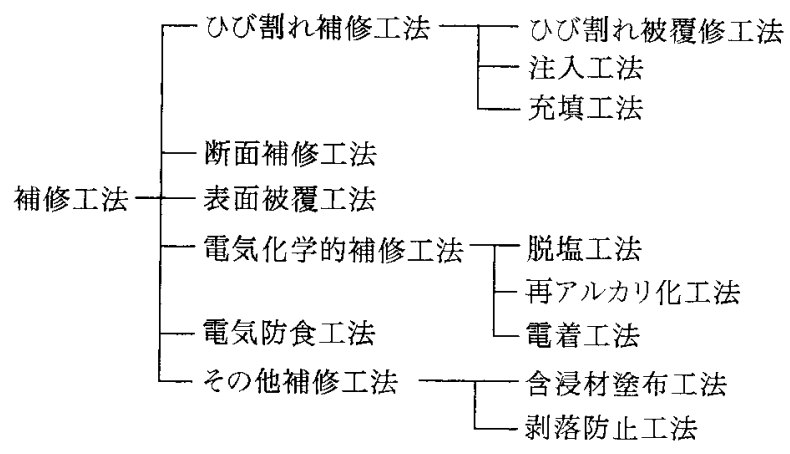

図 10 主な補修工法の種類 4

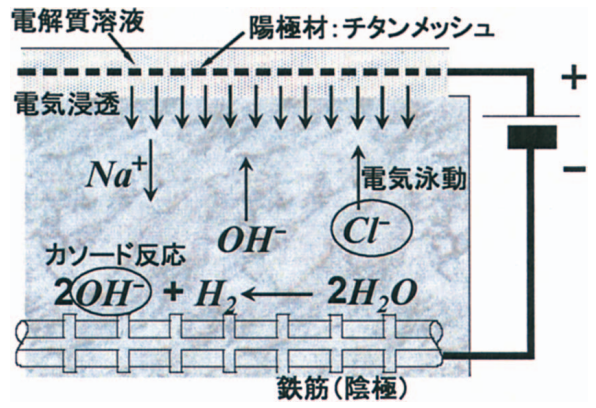

図 11 脱塩・再アルカリ化工法の原理

このような補修・補強工法を適用する際に今 後必要となるのは, 各工法が構造物の性能に与 える影響を明確にし，それによる延命期間を定 量的に示すことである. 補修工法が構造物の性 能や延命期間に与える影響を概念的に示したの が図 12 である. 図 12 の上のグラフは縦軸が工 法の性能低下を示しており, 下のグラフは構造物の性能 低下を示している。例えば，表面被覆工法を例に取ると， コンクリート表面に接着した表面被覆材は経時的に劣化 し，コンクリート表面との付着強度も低下していく。こ れが工法の性能低下であるが，工法を適用した構造物は， 工法の適用によって一度は上昇した性能が，その後は工 法の性能低下の影響を受けつつ, 構造物としての性能も 経時的に低下する。このような工法と構造物の相関関係 を考慮した性能の経時変化を捉えることで，工法による 延命効果が算出できる. 今後のデー夕の蓄積によってこ のような効果を精度良く評価できるモデルの構築が必要 である。

\section{5. シナリオデザイン}

近年, 構造物に要求される本来のコストとして，ライ フサイクルコスト（LCC）を用いるべきであるというこ とがようやく認められるに至っている。しかし，ライフ サイクルコストは，性能照査と同様に単なる計算技術で

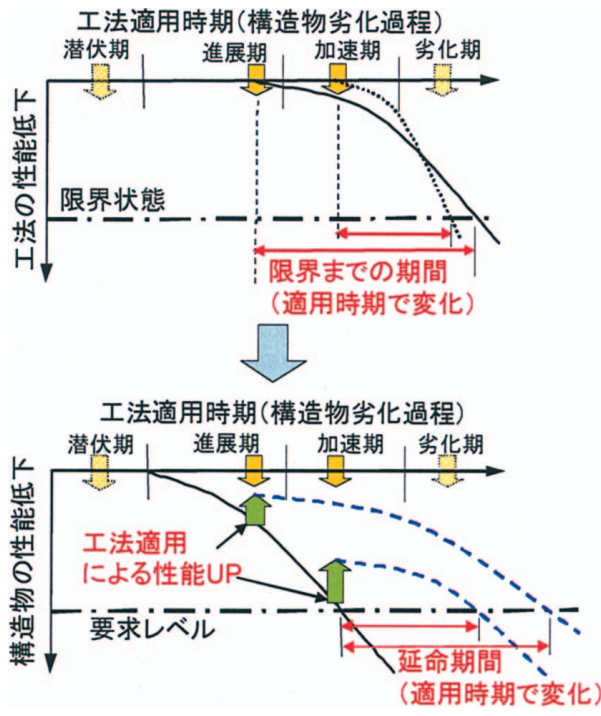

図 12 補修工法の適用が構造物の性能に与える影響9) 
あり，ライフサイクルの基本となるシナリオを創造する 能力こそが今要求されている。これにより，コンクリー 卜構造物を空間的にも時間的にも自由自在に設計できる と言えるのであって，21 世紀の “持続可能な発展”を達 成することができるのである。

コンクリート構造物の劣化に対して, 適切な対策を策 定するためには, シナリオの構築と選定がきわめて重要 である．構造物をどのように機能させたいかあるいはす るべきか，という空間的かつ時間的なシナリオがあって 初めて LCC などの具体的な算出が可能となる。例えば 前述の図 7 においては, 補修工法の適用時期として, 構 造物の劣化段階の進展期とした場合と，加速期とした場 合のイメージを示している．図 7 を塩害の例で考えると， コンクリート中の鉄筋腐食は開始しているが，腐食ひび 割れは顕在化していない進展期に補修工法を適用した場 合，腐食ひび割れが拡大する加速期に適用した場合と比 較して, 工法自身の性能低下速度が小さく，これに伴っ て工法の限界までの期間および構造物が要求レベルを満 たす延命期間が長くなっている.すなわち，早めの対策 が効果を増大させるということを示している。これも一 つのシナリオ比較例であるが，適切なシナリオに基づい てコストあるいはリスクなどを計算し，その最適化を元 に維持管理を行った場合にはじめて, 構造物のマネジメ ントは適切なものとなる.

社会基盤構造物の多くは市民のものである。したがっ て，構造物をどのように使いこなすかについてのシナリ オを市民に説明する責任が技術者にはある。コンクリー 卜構造物の性能, 品質を語る場合, それの本来の所有者 あるいは利用者である市民に対する説明責任を果たすた めの努力が必要な時代が到来しつつあると言える.

\section{6. おわりに：腐食工学に期待するもの}

本稿では，コンクリート構造物の劣化問題について概 観したが，本来のコンクリート構造物は “美しく，丈夫 で，長持ち”するべきものであり，私たちはこのような 良質の資産を後世に残していく義務がある。このような
義務を果たしていくためには，コンクリート構造物の複 雑な劣化現象に適切に対処していかなくてはならない. その際には，コンクリート工学の知識や技術だけでは自 ずと限界がある。例えば，コンクリート中の鉄筋腐食問 題を検討するには, 金属工学, 腐食工学, 電気化学など の専門知識が不可欠である。これらの専門知識を有する 本誌読者諸氏においては，是非ともコンクリートの分野 にも興味を持っていただき，今後の活発な交流を期待す るものである．本稿がこのような異分野交流のきっかけ となれば望外の喜びである.

\section{参 考 文 献}

1）土木学会，構造物表面のコンクリート品質と耐久性能検 証システム研究小委員会 (335 委員会) 成果報告書扔よび シンポジウム講演概要集，コンクリート技術シリーズ 80 (2008).

2) T. Miyagawa, Contr. J. JCI, 36 [7] 4 (1998).

3）日本建築学会，鉄筋コンクリート造建築物の耐久性調 查・診断㧍よび補修・補強指針 (案) ・同解説 (1997).

4）日本コンクリート工学協会，コンクリート診断技術’09 (2009).

5）土木学会，アルカリ骨材反応対策小委員会報告書一鉄筋 破断と新たなる対応一，コンクリートライブラリー, No.124 (2005).

6) Toyoaki Miyagawa, Kaoru Seto, Kazunori Sasaki, Yasuhiro Mikata, Kazuhiro Kuzume and Toshikazu Minami, Fracture of reinforcing steel in concrete structures damaged by alkali-silica reaction - Field survey, mechanism and maintenance, Journal of Advanced Concrete Technology, 4 [3] 339 (2006).

7）佐々木孝彦，宮川豊章，松山晋作，飯島 亨，アルカリ 骨材反応による鉄筋破断事例, 土木学会第 61 回年次学 術講演会講演概要集 5, p.111 (2006).

8) Masato Kobayashi, Atsushi Nishikawa and Tooru Tsuru, Hydrogen embrittlement of reinforced steel in high alkaline environments, Marine Corrosion and Control, p.93 (2006).

9）土木学会，コンクリート中の鋼材腐食性評価と防食技術 研究小委員会 (338 委員会) 委員会報告書 (2009).

10）（財）エンジニアリング振興協会，自然電位によるコンク リート中の鋼材の腐食発生限界塩化物イオン濃度試験方 法 (案), 戦略的技術開発 (構造物長寿命化高度メンテナ ンス技術開発) (2007).

11) T. Miyagawa and T. Ueda, Contr. J. JCI, 38 [3] 9 (2000).

(2009 年 11 月 12 日受理)

\section{要旨}

コンクリート構造物は, 塩害や中性化, アルカリ骨材反応といった様々な劣化機構によって, 経時的に 性能が低下していく．このような構造物を適切に維持管理していくためには，まだ種々の問題があるのが 現状である．本稿では，コンクリート構造物の劣化問題を概観するとともに，コンクリート中の鉄筋腐食 問題を中心に，今後の維持管理システム構築にあたっての取り組みの現状と，解決すべき問題点を示す. キーワードコンクリート構造物, 劣化機構, 鉄筋腐食, 維持管理システム, 補修・防食工法, シナ リオデザイン 